\title{
Very high-resolution seismic definition of glacial and postglacial sediment bodies in the continental shelves of the northern Trinity Peninsula region, Antarctica
}

\author{
M. Canals, ${ }^{1 *}$ F. Estrada, ${ }^{2 *}$ R. Urgeles,${ }^{1 *}$ GebraP $96 / 97$ Team $^{\dagger}$ \\ ${ }^{1}$ Universitat de Barcelona, Dept. Estratigrafia i Paleontologia, E-08071 Barcelona, Spain \\ ${ }^{2}$ Institut de Ciències del Mar, Dept. Geologia Marina i Oceanografia Física, E-08039 Barcelona, Spain
}

\begin{abstract}
The sea-floor morphological features and sedimentary cover on the shelves of the northern Trinity Peninsula, Antarctica, result from glaciomarine processes. Roughness of the sea floor is apparent at scales from kilometre-wide glacial troughs to metre-wide iceberg scours. The sedimentary cover is unequally distributed, with a preference for sheltered areas and sea-floor depressions where deposition obeys local controlling factors. An uppermost draping layer caused by settling of fine particles was observed in several of the studied settings. Large parts of the shelves are devoid of sediments, and there the sea floor shows widespread, mostly relict evidence of glacial erosion. The observed sea-floor morphologies and sedimentary cover highlight the return to grade of the shelves from the northern Trinity Peninsula region.
\end{abstract}

\section{INTRODUGTION}

The continental shelves of the northern Trinity Peninsula region $\left(67-57^{\circ} \mathrm{W}, 62-65^{\circ} \mathrm{S}\right)$, Antarctica, have been investigated by means of a PS018 TOPAS Bottom Parametric Source (BPS) system, which provides very high-resolution seismic profiles (10 $\mathrm{m}$ horizontal, $1 \mathrm{~m}$ vertical). BPS profiling is coupled with swath bathymetry and side-scan mapping along the same tracks (Fig. 1). The dataset covers (1) the shelf off Brabant and Anvers Islands, (2) the Gerlache Strait, (3) the southern shelves of King George and Livingston Islands in the Bransfield Basin, and (4) the outer shelf of the Trinity Peninsula also in the Bransfield Basin. Previous studies of shelf morphology and sediments in this area include Larter and Cunningham (1993), Pudsey and others (1994), Vanneste and Larter (1995) and Ercilla and others (in press).

\section{RESULTS}

The shelf off Brabant and Anvers Islands, Palmer Archipelago, is a $102 \mathrm{~km}$ wide landward-dipping surface. The sea floor of the shelf is very rough, and particularly uneven at the inner-mid shelf. The mid-outer shelf, where sea-floor microtopography remains rough, is marked by several smooth highs and troughs with a U-shaped cross-section. The shelf edge is at about $500 \mathrm{~m}$ water depth and is formed by a sedimentary flat-topped mound or shelf-edge bank bounded offshore by a steep slope $(23 \%)$. The bank is composed

* UA Geociències Marines CSIC-UB.

† The GEBRAP 96/97 team: A. M. Calafat, J. Sorribas, B. Alibés, I. Cacho, J. L. Casamor, J. Fabrés, M.J. Prieto, M. A. Rodríguez, M. Farran, F. Ramil, M. A. O. De Batist, T. van Cauwenberghe, P. Journet, J. Prades, C. Mir, R. Forcada.

rg/683189/1998AoG27-1-260-264 Published online by Cambridge University Press mainly of subglacially transported sediment, deposited by ice diverging from the mouth of an ice stream (Vanneste and Larter, 1995).

Most of the inner-mid shelf presents a rocky sea floor with no acoustic penetration, especially the shallower inner shelf which is scoured and largely sediment-free since it was cleared from the Last Glacial Maximum (LGM) ice cover later than the outer and mid shelf, probably before $6000 \mathrm{BP}$

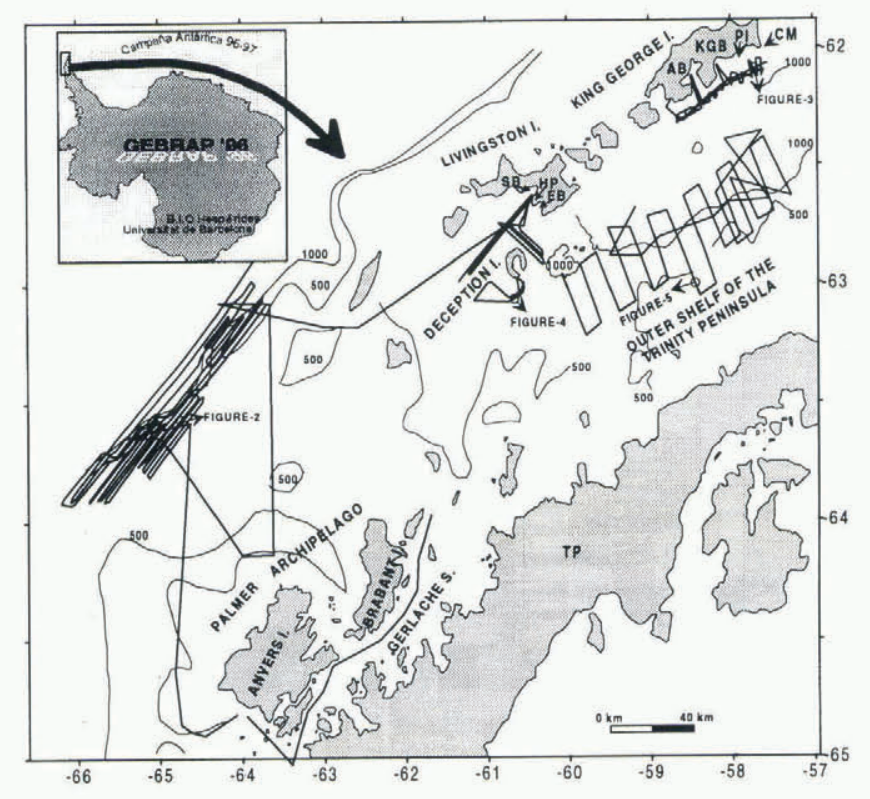

Fig. 1. Map of the study area, showing the position of the simultaneous BPS, multibeam bathymetry and side-scan lines, and locations of Figures 2-5. AB, Admiralty Bay; KGB, King George Bay; SB, South Bay; FB, False Bay; HP, Hurd Peninsula; TP, Trinity Peninsula; PI, Penguin Island; CM, Cape Melville. 


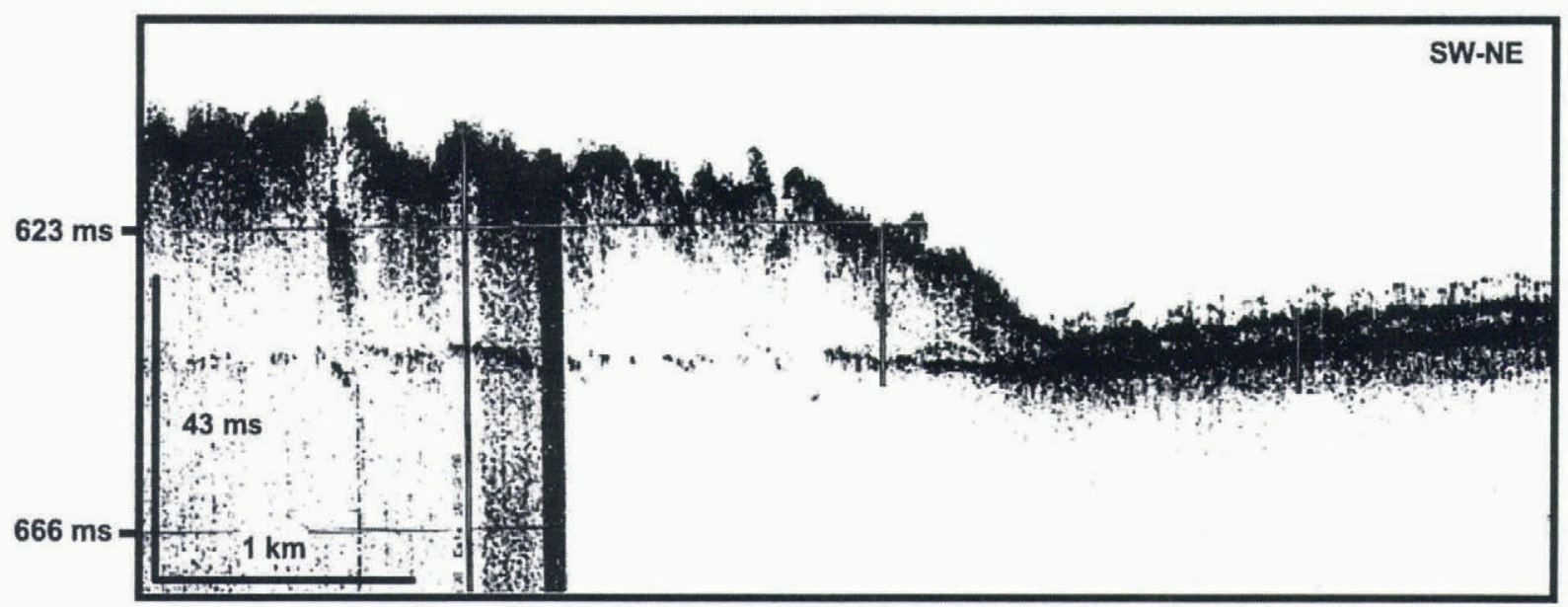

Fig. 2. Section of BPS profile, illustrating a till deposit with a rough top made of semi-transparent facies. Note the strong bottom reflector that bounds the base of the lens-shaped sediment body. The small troughs on top correspond to iceberg scours. Location in Figure 1.

(Pudsey and others, 1994). Late-stage readvances of grounding lines during the waning of the last ice sheet to cover the shelf could be responsible for some of the observed morphosedimentary features, such as subglacial deltas (Vanneste and Larter, 1995). Locally, patches of hemipelagic sedimentary cover up to $20 \mathrm{~ms}$ thick have been observed, mostly on the mid-shelf area. This cover is made of semi-transparent, stratified facies and is parallel-stratified with chaotic interlayerings near the steeper slopes.

Where present, the sedimentary cover on the mid-outer shelf is mainly formed by an association of unstratified, semi-transparent to chaotic facies, occasionally constituting lens-shaped bodies bounded by high-amplitude surfaces with characteristic microtopographies on top (Fig. 2), amongst which iceberg scours are clearly distinguishable on the side-scan images. This range of unstratified seismic facies on glacially modified continental shelves is usually considered indicative of diamicton lithofacies (Vorren and others, 1989; Stewart and Stoker, 1990; King and others, 1991; Vanneste and Larter, 1995). Prograded, acoustically unstratified deposits on the outer continental shelf off Anvers have been interpreted as relict subglacial deltas (Vanneste and Larter, 1995). Some larger depressions are filled by parallel-stratified facies, and a few terraces observed are capped by a thin cover $(<5 \mathrm{~ms})$ of semi-transparent to stratified facies. The high and trough topography and sedimentary cover observed on the mid-outer shelf is interpreted as the effect of ancient erosive ice streams and deposition of glacial tills (Fig. 2; Rebesco and others, 1997). Progradation of subglacial deltas would take place at the grounding lines of ice streams which flow on deforming subglacial till (Vanneste and Larter, 1995). Locally, a later hemipelagic drape exists on top of the till deposits. According to Larter and Cunningham (1993), the sedimentary mound at the above-mentioned shelf edge is also a till deposit left at the LGM. Our results, together with those of Larter and Cunningham (1993), Pudsey and others (1994) and Vanneste and Larter (1995), are relevant to the prospectus for the Ocean Drilling Program (ODP) drilling planned in the area for early 1998, particularly concerning the correlation between borehole lithologies and seismic facies on very high-resolution records from glaciomarine settings, and the history of the last glacial cycles in the Trinity Peninsula.
The Gerlache Strait, between the Palmer Archipelago and the Trinity Peninsula, is $190 \mathrm{~km}$ long and $7-40 \mathrm{~km}$ wide. Depth varies between $220 \mathrm{~m}$ in the western branch and $1300 \mathrm{~m}$ in the eastern branch. According to the BPS data, the Gerlache Strait lacks a continuous sedimentary cover. The sea floor on the western branch is predominantly rocky and rough, with highs and small depressions and fractures oriented north-south and north-northeast--south-southwest as observed on side-scan images. It represents the morphological continuation of the inner shelf off Brabant Island. The deeper eastern branch is less rugged.

The opaque facies is widely present along the strait, although restricted areas of stratified, semi-transparent and chaotic facies have also been observed. The opaque facies prevails in the western branch, while the stratified, semi-transparent and chaotic facies develop increasingly towards the eastern branch. In the middle of the Gerlache Strait a stratified sedimentary mound, at the mouth of a tributary channel, is defined by wavy reflections that onlap the northern slope of the strait. Towards the strait axis the configuration is retrogradational and downlapping. In the eastern branch of the Gerlache Strait two oversteepened troughs, $2 \mathrm{~km}$ wide, are filled by parallel-stratified, semitransparent and chaotic facies.

The stratal and growth pattern of the sedimentary mound in the middle of the strait could be interpreted as a drift developed by currents that stack the sediment load towards the sides of the main channel. The stratified, semitransparent and chaotic facies in the troughs of the eastern branch can be linked to specific glaciomarine processes: the stratified facies could be the result of hemipelagic draping, the chaotic facies are related to till deposits, and the semitransparent facies could be formed by structureless glacial mud or mass flows.

The southern shelf of King George Island is an uneven, rather rectilinear surface, $6 \mathrm{~km}$ wide in the southwestern half and $9 \mathrm{~km}$ wide in the northeastern half. The inner shelf is limited by a morphological step at about $100 \mathrm{~m}$ water depth. The shelf is cut by two fjords perpendicular to the main coastline, Admiralty Bay to the west, and King George Bay to the east (Fig. 1). Admiralty Bay reaches $500 \mathrm{~m}$ axial depth, is symmetric with respect to the axis and opens at $650 \mathrm{~m}$ water depth in the upper slope. King George Bay has an axial depth of $400 \mathrm{~m}$, is irregular in shape and ends at $500 \mathrm{~m}$ 


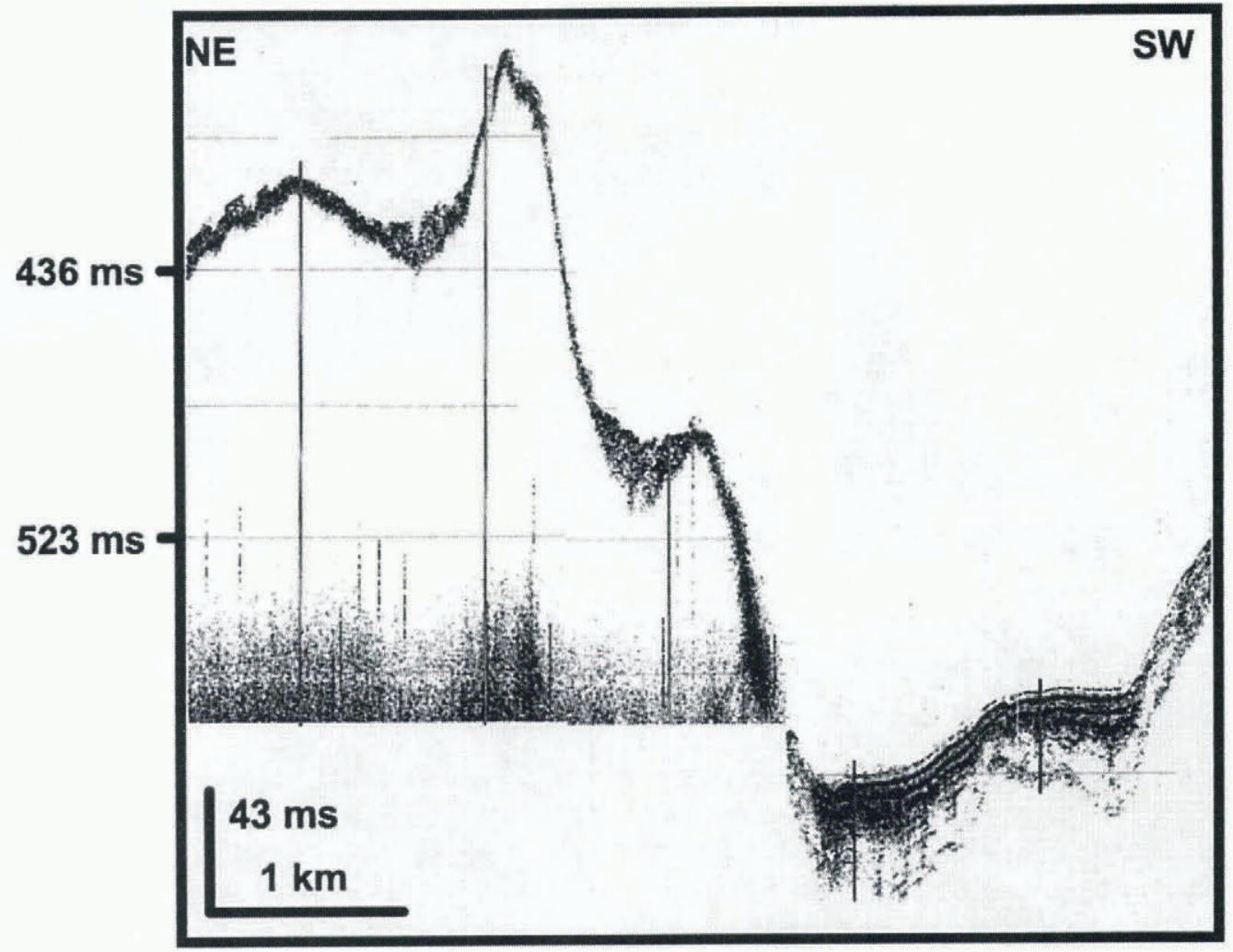

Fig. 3. Section of BPS profile, illustrating the very rough sea floor with dominant opaque seismic facies and no penetration between Penguin Island and Cape Melville, off the northeastern end of King George Island. Note the sedimentary wedge restricted to a local depression. The seismic facies is stratified with some reflectors of high amplitude separating sets of reflectors of low amplitude and very high frequency which look almost transparent. Location in Figure 1.

depth. In northeastern King George Bay, the shelf is very rough and is cut by two troughs reaching $300 \mathrm{~m}$ maximum depth.

Opaque, parallel-stratified, divergent-stratified, chaotic and semi-transparent acoustic facies are observed on the shelf, including fjords, for a maximum penetration of $75 \mathrm{~ms}$. The sedimentary cover is scarce in all the shallowest parts, with opaque seismic facies and no BPS penetration where the relief is particularly rough (Fig. 3). Fjords and local depressions on the open shelf contain significant sediment thicknesses with a good lateral continuity of the reflectors. Against morphological highs the cover is missing or chaotic (Fig. 3). Admiralty Bay's sediment cover is mostly stratified, except where it abuts on rocky highs and in nearshore areas where there are opaque and semi-transparent facies, respectively. King George Bay shows a thin, semitransparent cover confined to small depressions on the innermost shelf. That cover becomes continuous on the open shelf. Along the whole King George Island shelf, towards the slope break at about $100 \mathrm{~m}$, the relief becomes smooth and the seismic facies are mostly stratified. The northeastern shelf shows a thin, patchy cover $(<10 \mathrm{~ms})$ of semi-transparent facies in proximal areas.

The sedimentary processes on the King George Island

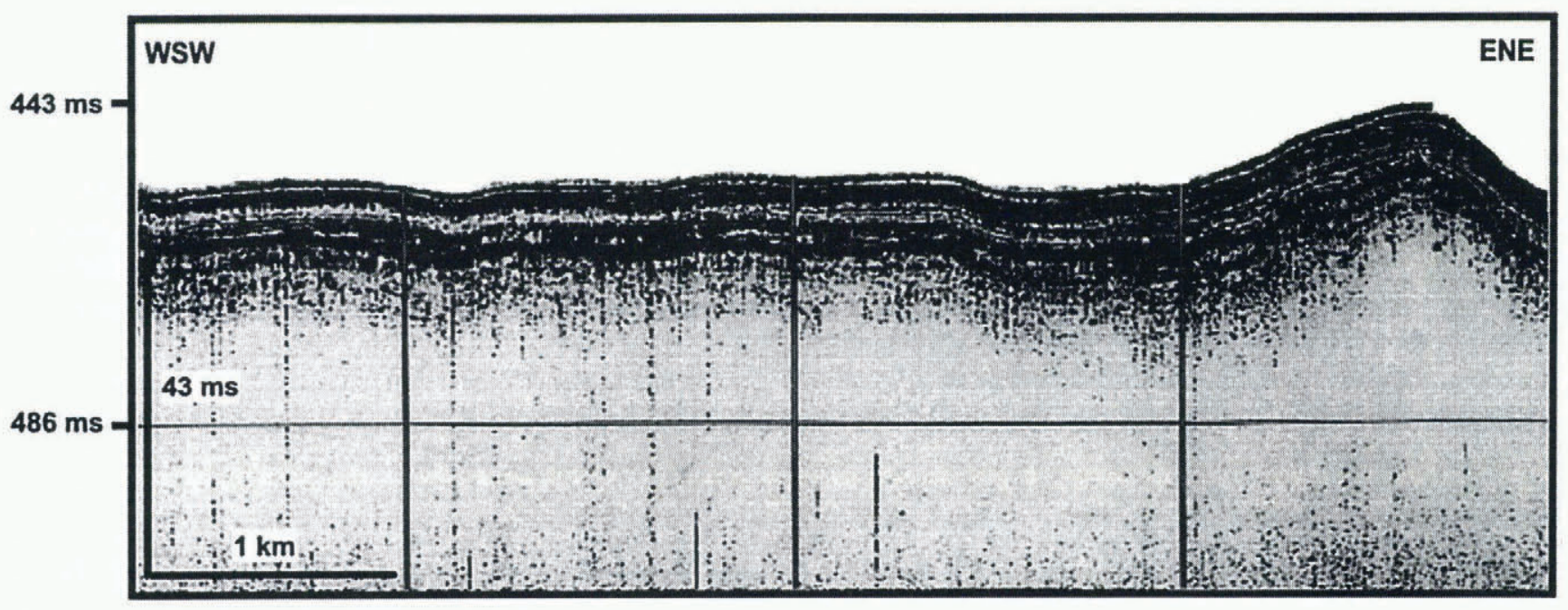

Fig. 4. Section of BPS profile, illustrating a sedimentary drape of probable mixed volcanic-glacial origin that covers part of the shelf near Deception Island. Location in Figure 1. 


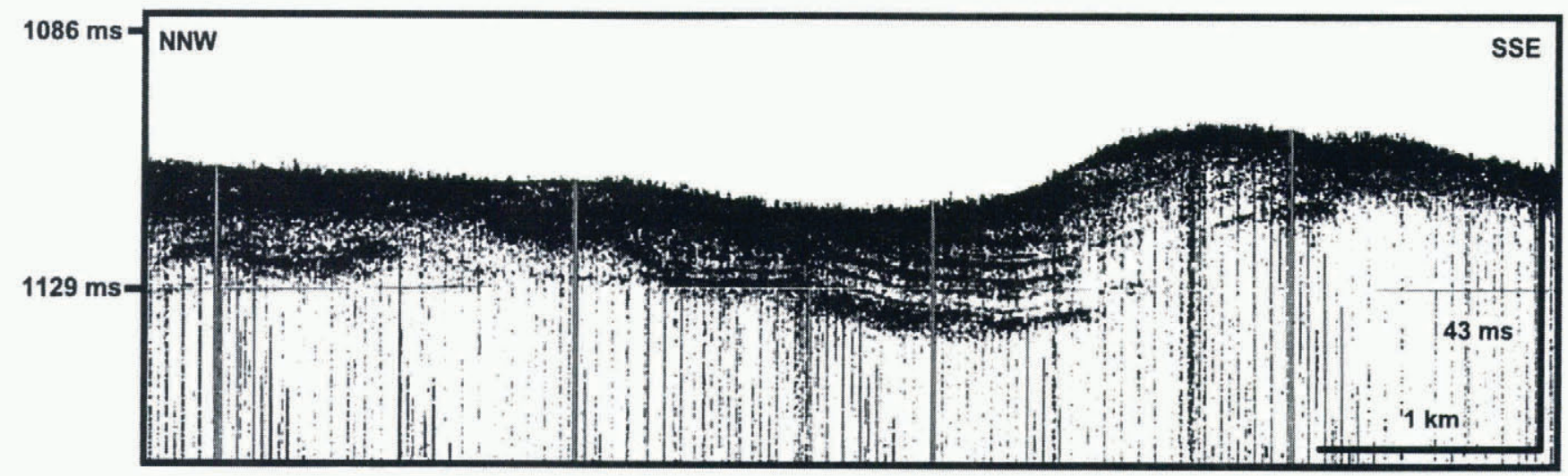

Fig. 5. Section of BPS profile, showing an erosive surface related to ice grounding that truncates the stratified facies below. Location in Figure 1 .

shelf are mainly controlled by the physiography. The sedimentary cover is scarce and is mostly supplied through the fjords, particularly Admiralty Bay, with part of the sediment load being deposited on the open shelf. Wedge configurations in small depressions can be related to faults. The semi-transparent facies observed in the protected fjords possibly correspond to relatively quiet sedimentation which would favour settling of fine, glacial-derived particles.

The shelf west of Livingston Island, off False Bay and Hurd Peninsula, also forms a rough surface down to $500 \mathrm{~m}$ water depth. A glacial trough connected with South Bay is clearly distinguishable on the sea floor. Southwest of nearby Deception Island, swath bathymetry data reveal a relatively smooth shelf (Figs 1 and 4).

The acoustic facies observed in this area are mainly opaque, parallel-stratified and chaotic, with a patchy distribution. The opaque and chaotic facies are mostly associated with small troughs also observed on side-scan images. The parallel-stratified facies forms a thin cover $(5 \mathrm{~ms})$ near Deception Island and Livingston, where it becomes thicker and more patchy, with intervals of chaotic facies. Off Livingston, the shelf shallows towards the shelf edge, and the acoustic response is opaque, probably because of the lack of sedimentary cover. One of the two highs bordering the above-mentioned glacial trough connected with South Bay, off Livingston, does not show any sedimentary cover, while the other trough has a thin sedimentary cover $(5 \mathrm{~ms})$ made of parallel-stratified facies.

In general terms, the sedimentary cover off Livingston and Deception is rather thin and locally absent, only widely draping the sea floor near Deception Island. Part of that cover may be of volcanic origin directly related to eruptions on Deception Island which have lasted till the present day (Gracia and others, 1996).

The outer shelf of the Trinity Peninsula is essentially smooth at a large scale but rough in detail, with several morphological highs and wide glacial troughs. The outer-shelf depth is $400-800 \mathrm{~m}$.

The facies present in this area are parallel-stratified, semi-transparent and opaque. The maximum penetration is $25 \mathrm{~ms}$. The parallel-stratified facies wedge towards the slope and the inner shelf, and in some places are truncated (Fig. 5). The semi-transparent facies is locally found under the stratified reflectors, while the opaque facies have been observed in the morphological highs. In outline the outer shelf of the Trinity Peninsula is cut by glacial channels related to ice streams, and basically is an erosional surface which today is patch-filled by a thin hemipelagic cover (Prieto, 1996). Glacial channels probably developed much earlier than the last glaciation, but have been repeatedly occupied by ice, including at the LGM. The surface roughness observed in the detailed scale probably corresponds to iceberg scours, which are widespread in this area (Ercilla and others, in press).

From the assembled observations on sea-floor morphological features and sedimentary cover on the shelves of the northern Trinity Peninsula the question arises how appropriate is the classical concept of grade on Antarctic shelves (Swift, 1970). Grading of a shelf means formation of a texturally graded shelf and finally an equilibrium profile following "natural cyclic periods" (Moore and Curray, 1964). Even if mesoscale troughs on the Trinity Peninsula shelf are being filled in, Pudsey and others (1994) concluded that the landward dip of the shelf would not be totally reversed during an interglacial period before the next ice advance. Obviously, grading at specific shelf segments will occur depending on the duration of each interglacial period, energy input, rates of sedimentation and subsidence, and other factors which control shelf sedimentation, such as glaciomarine processes in glaciated shelves (Swift, 1970). What mid-latitude and high-latitude, glaciated shelves hold essentially in common regarding grading are that (i) their morphosedimentary evolution follows cyclic patterns, and (ii) they have distinct inner, mid and outer shelves with specific processes and morphosedimentary features. However, the concept of "graded shelf" should be reviewed when applied to glaciated shelves, because of its very different environmental setting compared with mid-latitude shelves.

\section{GONCLUSIONS}

Most of the sea-floor shelf in the study area is erosional, as proven by the many glacial relict features, and devoid of postglacial sediments. Iceberg scours are widely distributed down to $800 \mathrm{~m}$ water depth. Postglacial sediments appear in three main settings: (a) fjords cut into the coast, as in Admiralty Bay, King George Island; (b) filling mid-shelf depressions, as in the shelf off Brabant and Anvers Islands; (c) at the mouth of channels feeding into larger channels, as in the Gerlache Strait. Postglacial sediments show a significant variety of sea-floor morphologies and seismic facies 
which are related to the processes from which they originate. Rough to smooth microtopographies, as well as mounded, fill, wedge and draping geometries, have been identified. Most of these geometries correspond to specific seismic facies, from semi-transparent to stratified. The overall conclusion is that recent glaciomarine sedimentation on the continental shelves of the northern Trinity Peninsula region is, at present, adjusting to the conditions created after the last glacial retreat in a cyclic although probably limited return to grade.

\section{ACKNOWLEDGEMENTS}

The research work for this paper was funded by the CICYT (project ref. ANT95-0889-C02-01). Background funding was also received from CIRIT of the Generalitat de Catalunya as GRCs. We thank the captain, officers, crew and UGBO technicians of the Spanish R/V Hésperides, for their assistance during the GEBRAP 96/97 cruise. We also acknowledge the constructive comments by C.J. Pudsey and D. Franklin who reviewed the first manuscript.

\section{REFERENCES}

Ercilla, G., J. Baraza, B. Alonso and M. Canals. In press. Recent geological processes in the central Bransfield Basin (western Antarctic Peninsula). In Stoker, M. S., D. Evans and A. Cramp, eds. Geological processes on continental margins: sedimentation, mass-wasting and stability. London, Geological Society.

Gracia, E., M. Canals, M. Farran, M.J. Prieto, J. Sorribas and GEBRA
Team. 1996. Morphostructure and evolution of the central and eastern Bransfield Basins (NW Antarctica). Mar. Geophys. Res., 18, 429-448.

King, L. H., K. Rokoengen, G. B. J. Fader and T. Gunleiksrud. 1991. Tilltongue stratigraphy. Geol. Soc. Am. Bull., 103(5), 637-659.

Larter, R. D. and A. P. Cunningham. 1993. The depositional pattern and distribution of glacial-interglacial sequences on the Antarctic Peninsula Pacific margin. Mar. Geol., 109, 203-219.

Moore, D. G. and J. R. Curray. 1964. Wave-base, marine profile of equilibrium, and wave-built terraces: discussion. Geol. Soc. Am. Bull., 75, 1267-1274.

Prieto, M.J. 1996. Estratigrafía sísmica y evolución geodinámica de la Cuenca Central de Bransfield (Antártida Occidental). (M.Sc. thesis, Universitat de Barcelona.)

Pudsey, C. J., P. F. Barker and R. D. Larter. 1994. Ice sheet retreat from the Antarctic Peninsula shelf. Continental Shelf Res., 14(15), 1647-1675.

Rebesco, M., R. D. Larter, P. F. Barker, A. Camerlenghi and L. E. Vanneste. 1997. The history of sedimentation on the continental rise west of the Antarctic Peninsula. In Barker, P. F. and A. K. Cooper, eds. Geology and seismic stratigraphy of the Antarctic margin, 2. Washington, DC, American Geophysical Union, 29-50. (Antarctic Research Series 71.)

Stewart, F.S. and M. S. Stoker. 1990. Problems associated with seismic facies analysis of diamicton-dominated, shelf glacigenic sequences. GeoMar. Lett., 10, 151-156.

Swift, D. J. P. 1970. Quaternary shelves and the return to grade. Mar. Geol., 8, 5-30.

Vanneste, L. E. and R. D. Larter. 1995. Deep-tow boomer survey of the Antarctic Peninsula Pacific margin: an investigation of the morphology and acoustic characteristics of Late Quaternary sedimentary deposits on the outer continental shelf and upper slope. In Cooper, A. K., P. F. Barker and G. Brancolini, eds. Geology and seismic stratigraphy of the Antarctic margin.. Washington, DC, American Geophysical Union, 97-121. (Antarctic Research Series 68.)

Vorren, T. O., E. Lebesbye, K. Andreassen and K. B. Larsen. 1989. Glacigenic sediments on a passive continental margin as exemplified by the Barents Sea. Mar. Geol., 85, 251-272. 